\title{
Optimization of biogas production from water hyacinth (Eichhornia crassipes)
}

\author{
${ }^{* 1}$ Rozy, ${ }^{2}$ Rouf Ahmad Dar and ${ }^{3}$ Urmila Gupta Phutela \\ *1,2 Department of Microbiology, Punjab Agricultural University \\ ${ }^{3}$ School of Renewable Energy and Engineering, Punjab Agricultural University, Ludhiana-141004 (Punjab), \\ INDIA \\ *Corresponding author. E-mail: rozysohni04@gmail.com
}

Received: December 14, 2016; Revised received: April 20, 2017; Accepted: September 25, 2017

\begin{abstract}
The present investigation reports the optimization of process parameters for biogas production from water hyacinth (Eichhornia crassipes). The different parameters like particle size, inoculum concentration, incubation temperature, metal ions and $\mathrm{pH}$ were optimized for biogas production. Maximum biogas was observed with water hyacinth of $1 \mathrm{~cm}$ size, $40 \%$ inoculum concentration. The temperature of $45^{\circ} \mathrm{C}$ along with neutral pH i.e. 7 was found to be most suitable for biogas production in the presence of manganese chloride $(0.2 \mathrm{mM})$. Under optimized conditions, 44.9 I biogas $/ \mathrm{kg}$ water hyacinth, $360.09 \mathrm{l} / \mathrm{kg}$ total solids and $397.95 \mathrm{I}$ biogas $/ \mathrm{kg}$ volatile solids were produced in a period of 40 days. The water hyacinth has proven to be a good source of biogas production and thus can be utilized as a potential feedstock for the biogas production.
\end{abstract}

Keywords: Biodigested slurry, Biogas, Cattle dung, Eichhornia crassipes

\section{INTRODUCTION}

Water hyacinth (Eichhornia crassipes), a monocotyledonous freshwater aquatic plant, member of family "Pontederiaceae". It is a local inhabitant to the Amazon Basin in Brazil and other nearby South American countries (Chunkao 2012). This tropical plant developed throughout the world in late 19th and early 20th century (Wilson et al 2005). In india, water hyacinth has distributed over 2,92,000 hectares of water surface in the country and its buoyancy has been highly perceived throughout the course of the river Thamirabarani, a perennial river in south India (Murugesan, 2002; Murugesan 2001).

E. crassipes can be used in waste water treatment, heavy metal and dye remediation, as basis for bioethanol and biogas production, electricity generation, industrial uses, medicines, animal feed, agriculture (Patel 2012). It can be used as a potential feedstock for biogas production due to its exuberance and high carbon nitrogen ratio of 15 . Biogas contains $49 \%-53 \%$ methane $\left(\mathrm{CH}_{4}\right), 30 \%-33 \%$ carbon dioxide $\left(\mathrm{CO}_{2}\right), 5 \%-6$ $\%$ nitrogen $\left(\mathrm{N}_{2}\right)$ and traces of hydrogen sulphide $\left(\mathrm{H}_{2} \mathrm{~S}\right)$. Biogas technology amongst other processes (including thermal, combustion and gasification) has been judged as a better source of sustainable waste treatment as disposal of wastes has become a major difficulty especially to the third world countries (Arvanitoyannis et al 2008). It provides a suitable source of renewable energy. It holds the highest possi- bility for utilization of materials like plant and animal wastes, as source of fuels through anaerobic fermentation and thus can meet the basic requirement for cooking and lightening in rural areas.

Water hyacinth has been used as a source of biogas production. Various strategies have been adopted for enhancement in biogas production. Njogu et al (2015) used solid adsorbents and wet scrubbers that increased methane concentration by $70-76 \%$. Codigestion experiment of water hyacinth with cow dung and food wastes as inoculums have also been tried. These led to an increment in the estimated value of biogas production (Kumar et al 2016). There is still much to do in the area of evaluating the effect of different physicochemical parameters on biogas production from water hyacinth. So there is need to optimize the process of biogas production from water hyacinth, E. crassipes. Therefore the present study was designed to optimize various parameters (particle size, inoculum concentration, incubation temperature, heavy metal ions and $\mathrm{pH})$.

\section{MATERIALS AND METHODS}

Procurement of the materials: Fresh water hyacinth was collected from the ponds located near Shiv Temple in Haibowal, Ludhiana (Punjab). Cattle dung was procured from Dairy farm, Guru Angad Dev Veterinary and Animal Science University (GADVASU), Ludhiana (Punjab). Biodigested slurry was procured 
from a working biogas plant in Biogas Field Laboratory of School of Renewable Energy and Engineering, Punjab Agricultural University (PAU) Ludhiana.

Effect of different physico-chemical factors on biogas production: The change in chemical (Total solids, Volatile solids and ash) and proximate (cellulose, hemicellulose, lignin and slilica contents) composition of water hyacinth was taken as a criteria for the production of biogas.

Effect of milling: Evaluation of particle size on biogas production was studied by chopping the water hyacinth $(500 \mathrm{~g})$ into different dimensions $(1 \mathrm{~cm}, 2 \mathrm{~cm}$ and 3 $\mathrm{cm})$ by chopping machine. Then it was soaked in hot water for 60 minutes and was fed to anaerobic digester for biogas production.

Effect of inoculum concentration: Different concentrations of inoculum (10-50\%) were added to water hyacinth $(500 \mathrm{~g})$ for evaluating the effect on biogas production.

Effect of temperature: To evaluate the effect of temperature on biogas production, water hyacinth $(500 \mathrm{~g})$ was mixed in $500 \mathrm{ml}$ water and fed to the digesters. These digesters were then inoculated at different temperatures $\left(20,30,40\right.$ and $\left.45^{\circ} \mathrm{C}\right)$.

Effect of pH: $500 \mathrm{ml}$ water was added to the $500 \mathrm{~g}$ water hyacinth and the same was fed to the anaerobic digesters for biogas production. The $\mathrm{pH}$ of the digesters were set as 6,7 and 8 to determine its effect on biogas production. $\mathrm{pH}$ was set by using $0.1 \mathrm{~N} \mathrm{HCl}$ and $0.1 \mathrm{NaOH}$.

Effect of metal ions concentration: Different metal ions concentration $(0.2 \mathrm{mM}$ ferrous sulphate, $0.2 \mathrm{mM}$ ammonium sulphate, $0.2 \mathrm{mM}$ zinc sulphate, $0.2 \mathrm{mM}$ manganese chloride, $0.2 \mathrm{mM}$ urea and $0.2 \mathrm{mM}$ aluminium sulphate) were added to the digesters containing cow dung and biodigested slurry for the determination of their effect on biogas production.

Solid state anaerobic digestion setup for biogas production (SSAD): The water hyacinth exposed to different physic-chemical factors (milling, inoculum concentration, temperature, $\mathrm{pH}$, metal ion concentration) was subjected to biogas production. The untreated (control) and treated water hyacinth was digested in batch anaerobic digesters. The batch anaerobic system composed of a 21 glass reactor for feedstock, 21 glass bottle for gas collection which was filled with dilute hydrochloric acid solution $(\mathrm{pH}<3)$ to avoid $\mathrm{CO}_{2}$ dissolution) and 1 litre liquid collection beaker. Biogas production was measured by water displacement method i.e. by measuring the amount of water displaced by the gas produced in millilitre. The anaerobic digesters in triplicates pertaining to each treatment were set up. The digesters were mixed with $50 \mathrm{~g}$ cattle dung (acting as inducer) and $50 \mathrm{~g}$ cattle dung slurry (acting as inoculum). Reactors were then carefully examined for any leaks to inspect close tight rubber stopper and screw caps. The samples were taken both at the initial stage and after a period of 40 days for proximate and chemical analysis. Biogas production for each reactor was measured every day and level of water was maintained in gas collecting chamber.

Proximate and ultimate analysis: Standard methods of AOAC (2000) were followed for the determination of total solids, volatile solids, ash, cellulose, hemicellulose, silica and lignin at the beginning of the experiments and after 40 days at the time of biogas formation.

Statistical analysis: The data was analysed by Tukey's HSD $(p<0.05)$ method for multiple comparisons by using the Statistical Analysis System (SAS). The standard error (SE at 5\% level) was calculated for triplicate data.

\section{RESULTS AND DISCUSSION}

Effect of different physicochemical factors on biogas production from water hyacinth

Milling: The particle size depicts the importance of easily available safe and active sites for methanogens to grow. Water hyacinth was milled in various sizes $(1 \mathrm{~cm}, 2 \mathrm{~cm}, 3 \mathrm{~cm})$. The other set was grinded to fine powder. Biogas was produced from the above mentioned samples. The change in chemical (Total solids, Volatile solids and ash) and proximate (cellulose, hemicellulose, lignin and slilica contents) composition of water hyacinth was taken as a criteria for the production of biogas. Results from table 1 indicate a declining trend in the consumption of total solids, volatile solids, cellulose, hemicellulose, lignin and silica. The total solids in control decreased from $15.5 \%$ to $7.0 \%$ in 40 days, volatile solids from $83.4 \%$ to $56.4 \%$, cellulose content from $19 \%$ to $12.3 \%$ and hemicellulose content from $22.4 \%$ to $18.6 \%$. No significant difference was observed in the degradation of lignin and silica. The decrease in total solids (13.1 to $4.5 \%$ ), volatile solids (81.6 to $56.4 \%$ ), cellulose content $(22.8 \%$ to $10.5 \%$ ) and hemicellulose content (26.4 to $12.7 \%$ ) was found to be highest in case of $1 \mathrm{~cm}$ sized sample followed by $3 \mathrm{~cm}$ and $2 \mathrm{~cm}$ size. The results in case of grinded sample are comparable to that of $1 \mathrm{~cm}$ sized sample and do not differ significantly. Similarly highest biogas production was found in $1 \mathrm{~cm}$ sized sample (39.5 $\mathrm{lkg}^{-1}$ water hyacinth) which showed an increase of $19.2 \%$ over control as shown in table 2 . This may be due to the reason that small particle size resulted in greater amount of easily degradable organic matter which favoured methanogenesis (Angelidaki and Ahring 1993).

Inoculum concentration: Inoculum is a small amount of substance containing microorganisms from a pure culture which is used to start a new culture. Here biodigested slurry acts as an inoculum as it contains microbial consortium in activated form. Varying concentrations of inoculum $(10,20,30,40$ and $50 \%)$ were taken to estimate the biogas production. The chemical 


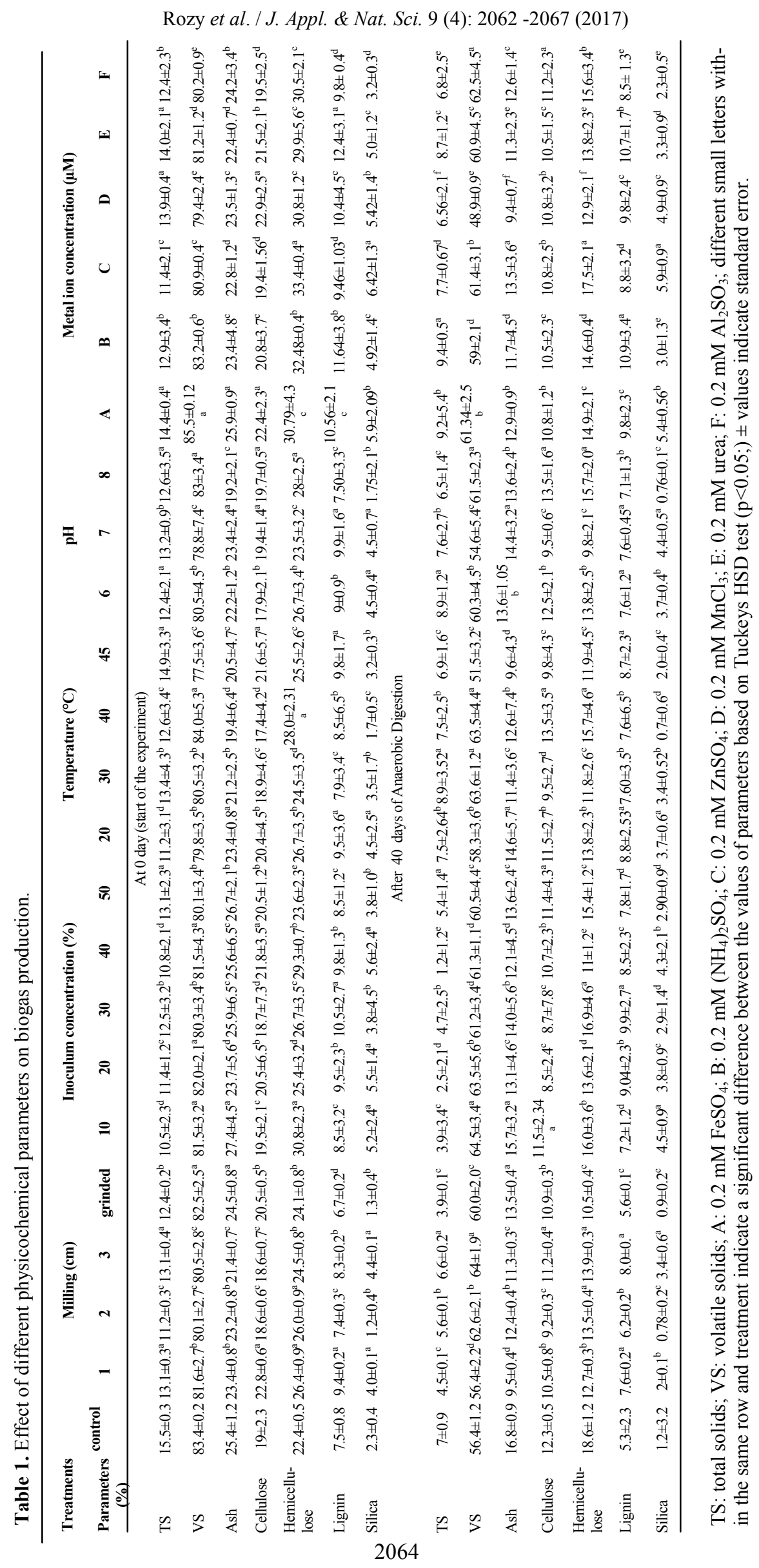


Rozy et al. / J. Appl. \& Nat. Sci. 9 (4): 2062 -2067 (2017)

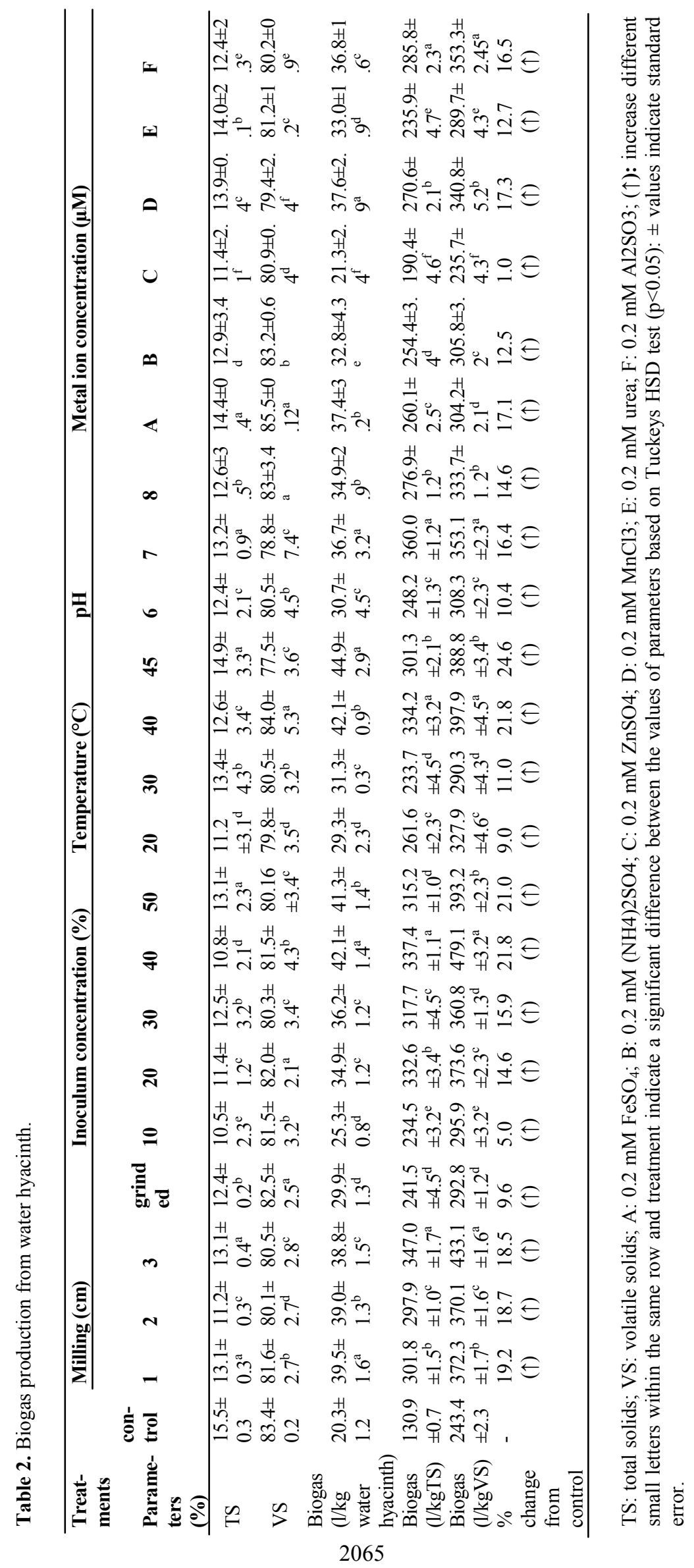


(TS, VS and ash) and proximate (cellulose, hemicellulose, lignin and silica contents) analysis contributes to the production of biogas. In case of digester having 40 $\%$ inoculum concentration, the reducing pattern was highly noticed. Highest reduction was observed in total solids (10.8\%-1.2\%), volatile solids (81.5-61.3\%), cellulose $(21.8-10.7 \%)$, hemicellulose $(29.3 \%-11 \%)$ followed by the digester having $50 \%$ inoculum concentration. Results are represented in table 1 . As a result greater biogas production was observed in case of $40 \%$ inoculum concentration $\left(42.1 \mathrm{lkg}^{1}\right.$ water hyacinth) which showed substantial enhancement of 21.8 $\%$ over control as shown in table 2 . This might be due to the reason that the cattle dung slurry which is rich in microbial consortium for biogas production helps in converting water hyacinth into biogas. At lower concentration, there are not sufficient microbes that could initiate the process of methanogenesis (Demirer et al 2004). At higher concentration of effluent grown biomass, methane content in the biogas was severely reduced to methanogenesis inhibition caused due to toxic effects of higher concentrations of metals (Singhal and Rai 2003).

Incubation temperature: Temperature for fermentation greatly affects biogas production. Depending on prevailing conditions methane can be produced within a wide range of temperature. Temperatures set up at the digester $\left(20,30,40\right.$ and $\left.45^{\circ} \mathrm{C}\right)$ showed highest biogas production $\left(42.1 \mathrm{~kg}^{-1}\right.$ water hyacinth) at $45^{\circ} \mathrm{C}$. Alternative temperatures were recorded $\left(20^{\circ} \mathrm{C}, 30^{\circ} \mathrm{C}\right.$, $40^{\circ} \mathrm{C}$ and $45^{\circ} \mathrm{C}$ ) for evaluating the production of biogas. A loss was estimated in the values of total solids, volatile solids, cellulose and hemicellulose content. The digester kept at incubation temperature $45^{\circ} \mathrm{C}$ showed highest decrease in total solids (14.9 to $6.9 \%$ ), volatile solids ( 77.5 to $51.5 \%$ ), cellulose (21.6 to 9.8 $\%$ ), hemicellulose (25.5 to $11.9 \%$ ) as compared to other digesters as depicted in table 1. Table 2 shows that highest biogas production was observed in the digester having $45^{\circ} \mathrm{C}\left(44.9 \mathrm{~kg}^{-1}\right)$ which showed an increase of $24.6 \%$ over control. At very low or high temperatures (e.g. temperatures below $-10^{\circ} \mathrm{C}$ or above $90^{\circ} \mathrm{C}$ ) microorganisms are destroyed completely. At such low temperatures the rate of organic matter conversion into biogas is minimized, since the activity of microorganisms is limited. They grow quickly in this temperature range and exhibit high degrees of conversion. Luostarinen et al (2005) also reported that $42^{\circ} \mathrm{C}$ temperature was the ideal temperature for the efficient production of biogas in anaerobic treatment of domestic wastewater. The production of biogas is fastest during summer and it decreases at lower temperature during winter. If the temperature is lower than $20^{\circ} \mathrm{C}$, the rate of gas production falls sharply and at about $10^{\circ} \mathrm{C}$ it almost ceases (Mahanta et al 2004).

pH: $\mathrm{pH}$ value indicates the degree of acidity or alkalinity of a solution. In the anaerobic digest- er, $\mathrm{pH}$ condition is important parameter because it affects bacterial activity to destroy organic matter to biogas. The $\mathrm{pH}$ of the biogas digesters were adjusted to 6,7 and 8 to measure the biogas production. In case of digester having $\mathrm{pH} \mathrm{7,} \mathrm{a} \mathrm{huge} \mathrm{decrease} \mathrm{was} \mathrm{ob-}$ served in case of total solids (13.2 to $7.6 \%$ ), volatile solids ( 78.8 to $54.6 \%$ ), cellulose (19.4 to $9.5 \%$ ), hemicellulose (23.5 to $9.8 \%$ ) followed by the results at $\mathrm{pH}$ 8 and $\mathrm{pH}$ 6. All these factors help in biogas production. So the highest production of biogas was observed in the digester with neutral $\mathrm{pH}\left(36.7 \mathrm{lkg}^{-1}\right)$ which increased by $16.4 \%$ over control. Results are shown in table 2. Lopes et al (2004) also reported that the maximum biogas was produced from cattle dung at $7 \mathrm{pH}$. This might be due to the reason that low $\mathrm{pH}$ values inhibited the activity of microorganisms involved in the biogas production especially methanogenic bacteria. Therefore biogas production is reduced at low $\mathrm{pH}$. At high $\mathrm{pH}$, activity of methanogens is also lowered. So neutral $\mathrm{pH}$ is required for maximum production of biogas whereas low and high $\mathrm{pH}$ is toxigenic to methanogenic activity.

Metal ion concentration: Heavy metals like iron, cadmium, mercury play a vital role in biogas generation by altering way of acidogens population in methanogenesis. Varying concentrations of different metal ions $(0.2 \mathrm{mM}$ ferrous sulphate, $0.2 \mathrm{mM}$ ammonium sulphate, $0.2 \mathrm{mM}$ zinc sulphate, $0.2 \mathrm{mM}$ manganese chloride, $0.2 \mathrm{mM}$ urea and $0.2 \mathrm{mM}$ aluminium sulphate) were supplemented in the digesters to evaluate the production of biogas. Decline was observed in the values of total solids, volatile solids, cellulose and hemicellulose content. The digester supplemented with $0.2 \mathrm{mM}$ manganese chloride showed maximum decline. Reduction in total solids (13.9 to $6.56 \%$ ), volatile solids ( 79.4 to $48.9 \%$ ), cellulose (22.9 to $10.8 \%$ ), hemicellulose (30.8 to $12.9 \%$ ) was noticed. Therefore the biogas production was observed highest in case of manganese chloride $\left(37.6 \mathrm{lkg}^{-1}\right)$ which showed $17.3 \%$ increase over control. Results are depiced in table 2. Maximum biogas was produced as manganese is a cofactor for enzymes especially for hydrolysis. Therefore it showed positive results for methanogenic activity. Karlsson et al (2012) also reported the same results that with use of manganese $(0.2 \mathrm{mM}$ manganese chloride) as a heavy metal, biogas enhanced upto certain limit. Similar results were also reported by Moorhead and Nordstedt (1993) that heavy metals like manganese chloride, ferrous sulphate both of concentration 0.5 ppm exhibit maximum production. The metal ions have been reported to serve micronutrients for methanogenic bacteria which might have enhanced methanogenesis and thus methane content in biogas (Salminen and Rintala 2002). The lower concentrations $(0.2 \mathrm{~mm})$ of these heavy metals also serve as micronutrients for methanogenic bacteria, which enhanced the process of methanogenesis and thus me- 
thane content in biogas.

\section{Conclusion}

The study showed that it is possible to produce biogas from water hyacinth. It forms an attempt to use the unwanted weeds as substrate for methane production. The different physicochemical parameters (particle size, inoculum concentration, incubation temperature, metal ions and $\mathrm{pH}$ ) in combination with cow dung and biodigested slurry were tried to produce biogas from water hyacinth and lucrative results were obtained. Maximum biogas production $\left(44.9 \mathrm{lkg}^{-1}\right.$ water hyacinth) was obtained at $45{ }^{\circ} \mathrm{C}$ as maximum degradation in terms of proximate and chemical composition was noticed in these sets. Further studies are needed for the optimization and enhancement of methane generation from water hyacinth and other such different substrates for their further use in such systems.

\section{ACKNOWLEDGEMENTS}

The authors acknowledge the financial support provided by AICRP-BCT (All India Coordinated Research Project, Bioconversion Technology) ICAR (Indian Council of Agricultural Research) for pursuing this project.

\section{REFERENCES}

Angelidaki, I. and Ahring, B.K. (1993). Thermophilic anaerobic digestion of livestock waste: effect of ammonia. Appl. Microbiol. Biotechnol. 38 :560-564.

AOAC (2000). Association of Official Analytical Chemists, Official methods of Analysis, J AOAC Int. 83 (4): 1020$25,17^{\text {th }}$ Edition, Maryland, USA

Arvanitoyannis, I.S. and Tserkezou, P. (2008). Corn and rice waste: a comparative and critical presentation of methods and current and potential uses, treated wastes. Int. J. Food. Sci. Technol. 43: 958-988.

Chunkao, K., Nimpee, C. and Duangmal. (2012). The King's initiatives using water hyacinth to remove heavy metals and plant nutrients from wastewater through Bueng Makkasan in Bangkok, Thailand. Ecol. Eng. 39 :40-52.

Demirer, G.N., Demirci, Duran, M., Erguder, T.H., Guven, E.U., gurlu, O. and Tezel, U. (2004). Anaerobic treatability and biogas production potential studies of different agro-industrial wastewaters in Turkey. Biodegradation. $11: 401-405$.

Karlsson, A., Einarsson, P., Schnürer, A., Sundberg, C., Ejlertsson, J. and Svensson, B. (2012). Impact of trace element addition on degradation efficiency of volatile fatty acids, oleic acid and phenyl acetate and on microbial populations in a biogas digester. J. Biosci. Bioeng. 114(4) :446-452.

Kumar, D. K. K. and Rajakumar, S. (2016). Review on biogas production from codigestion of cow dung and foodwaste with water hyacinth. Int. J. Res. Sci. Technol. 6

Lopes, W.S., Leite, V.D. and Prasad, S. (2004). Influence of inoculum on performance of anaerobic reactors for treating municipal solid waste. Bioresour. Technol. $94: 261-266$.

Luostarinen, S. A. (2005). Anaerobic on-site wastewater treatment at low temperature. Thesis. Department of Biological and Environmental Science. University of Jyväskylä, Finland.

Mahanta, P., Dewan, A., Saha, U. K. and Kalita, P. (2004). Effect of temperature and agitation on the Performance of Biogas Digesters. Proc $2^{\text {nd }} B S M E-A S M E$ International Conference on Thermal Engineering. Bangladesh. $2: 871-879$.

Moorhead, K. K. and Nordstedt, R. A. (1993). Batch anaerobic digestion of water hyacinth: Effects of particle size, plant nitrogen content and inoculum volume. Bioresour. Technol. 44(1):71-76.

Murugesan , A. G. (2002). Integrated biological control of water hyacinth (Eichhornia crassipes) in the fresh habitats of India. In Ecology and Ethology of Aquatic Biota, Daya Publishing House, New Delhi, India, 361-372.

Murugesan, A.G. (2001). Environmental status of the perennial river Thamirabarani with special reference to domestic and industrial pollution. Proc. Workshop on Enhancing Awareness of Ecological Status of River Basins 15-21.

Njogu, P., Kinyua, R., Muthoni, P. and Nemoto, Y. (2015). Biogas production using water hyacinth (Eicchornia crassipes) for electricity generation in Kenya. Energy. Power. Eng. 7 :209-216.

Patel, S. (2012). Threats, management and envisaged utilizations of aquatic weed Eichhornia crassipes: an overview. Rev. Environ. Sci. Biotechnol. 11 :249-259.

Salminen, E. and Rintala, J. (2002). Anaerobic digestion of organic solid poultry slaughterhouse waste - a review. Bioresour Technol 83 :13-26.

Singhal, V. and Rai, J. P. N. (2003) Biogas production from water hyacinth and channel grass used for phytoremediation of industrial effluents. Bioresour. Technol. 86 :221 -225 .

Wilson, J. R., Holst, N. and Rees, M. (2005). Determinants and patterns of population growth in water hyacinth. Aquatic. Botany. 81 : 51-67. 